УДК 338.24.01

DOI: https://doi.org/10.32782/2520-2200/2019-2-7

\begin{abstract}
Носань Н.C.
кандидат історичних наук, доцент, доцент кафедри економіки та підприємництва

Черкаського державного технологічного університету
\end{abstract}

Куценко Д.М. аспірант кафедри менеджменту та економічної безпеки Черкаського національного університету імені Богдана Хмельницького

Nosan Nataliya Cherkasy State Technological University

Kutsenko Dmytro

Bogdan Khmelnitsky National University of Cherkasy

ОСНОВИ ЗАБЕЗПЕЧЕННЯ ФІНАНСОВО-ЕКОНОМІЧНОЇ БЕЗПЕКИ HA MIKPO- TA MAKPOPIBHЯX: УКРАÏHCЬKI РEAЛIÏ

\title{
BASIS OF PROVISION OF FINANCIAL AND ECONOMIC SECURITY ON MICRO AND MACRO LEVELS: UKRAINIAN REALITIES
}

У статті узагальнено основи забезпечення фрінансово-економічної безпеки держави, а також встановлено характерні особливості процесу забезпечення фрінансово-економічної безпеки господарських структур. Запропоновано авторський підхід до розуміння сутності процесу забезпечення фінансово-економічної безпеки, а також до трактування самого поняття фрінансово-економічної безпеки. Визначено елементи комплексного забезпечення фрінансово-економічної безпеки на мікро- та макрорівнях. Виявлено особливості функціонування сучасних систем фрінансово-економічної безпеки держави та підприємств у вітчизняних економічних реаліях, висловлено припущення щодо недоліків організації процесу управління фрінансово-економічною безпекою на прикладному рівні. Запропоновано шляхи оптимізації забезпечення фрінансово-економічної безпеки, узагальнено набір стратегічних орієнтирів для зміцнення стану фрінансово-економічної безпеки сучасних підприємств та держави загалом.

Ключові слова: фрінансово-економічна безпека, забезпечення безпеки, суб'єкт господарювання, держава, загроза, ризик, концепція, стратегія.

В статье обобщены основы обеспечения финансово-экономической безопасности государства, а также установлены характерные особенности процесса обеспечения фринансово-экономической безопасности хозяйственных структур. Предложен авторский подход к пониманию сущности процесса обеспечения финансово-экономической безопасности, а также к трактовке самого понятия фринансово-экономической безопасности. Определены элементы комплексного обеспечения финансово-экономической безопасности на микро и макроуровнях. Выявлены особенности функционирования современных систем финансово-экономической безопасности государства и предприятий в отечественных экономических реалиях, высказаны предположения касательно недостатков организации процесса управления финансово-экономической безопасностью на прикладном уровне. Предложены пути оптимизации обеспечения фринансово-экономической безопасности, обобщен набор стратегических ориентиров для укрепления состояния фринансово-экономической безопасности современных предприятий и государства в целом.

Ключевые слова: финансово-экономическая безопасность, обеспечение безопасности, субъект хозяйствования, государство, угроза, риск, концепция, стратегия.

The article summarizes the fundamentals of the provision of financial and economic security of the state, as well as identifies the specific features of the process of ensuring the financial and economic security of economic structures. The author's approach to the understanding of the essence of the process of providing financial and economic security, as well as to the content interpretation of the concept of financial and economic security is proposed. With the provision of financial and economic security, it is offered to consider a complex of measures on the search and use of tools for detecting, counteracting threats, hazards and risks to the financial and economic activities of the subject, as well 
as compensating for the consequences of their negative impact and prevent their emergence in the future. The elements of the provision of financial and economic security include: the system of financial and economic security, entities of security, information principles, staffing component, management mechanism, resources, and tools. Their current state and level of functional ability to perform their assigned tasks determines the state of financial and economic security at the micro and macro levels. The peculiarities of the functioning of modern systems of financial and economic security of the state and enterprises in the national economic realities are revealed, and assumptions about the shortcomings of the organization of the process of management of financial and economic security at the applied level are expressed. It is advisable to include in the list of problems of securing financial and economic safety at micro and macro levels in domestic realities: absence of coordination between state, entrepreneurial, personal financial and economic interests, lack of periodic monitoring of the level of financial and economic security, fragmentation of the structure of its systems, lack of documentation of security management process, underfunding of protection measures from the adverse effects of hazards and threats, low level of training of security specialists to solve multidirectional tasks and rapid response to risk manifestations. The ways of optimizing the provision of financial and economic security are proposed and a set of strategic guidelines for strengthening the state of financial and economic security of modern enterprises and the state as a whole has been generalized.

Key words: financial and economic security, security supply, business entity, state, threat, risk, concept, strategy.

Постановка проблеми. На теоретичному та прикладному рівнях нині все частіше можна почути наполягання на необхідності забезпечення фінансово-економічної безпеки. В контексті державного управління перш за все йдеться про реформування вітчизняної економічної системи та переорієнтування її зі шляху екстенсивного на шлях інтенсивного розвитку не в останню чергу за рахунок еволюції фрінансового ринку та якісної трансформації його інфраструктури. Однак пріоритетом такого розвитку має визнаватись не нарощення фрінансового потенціалу держави будь-якою ціною, а орієнтація на убезпечення внутрішніх економічних та фрінансових ресурсів від можливості їх втрати в результаті надмірно ризикованого використання або через несумлінне ставлення посадових осіб до виконання покладених на них функцій та завдань. Крім того, орієнтований на безпеку фінансово-економічний розвиток має концентруватись на гарантіях гармонійного забезпечення реалізації економічних та фрінансових інтересів як держави, так і регіонів, суб'єктів господарювання, громадян 3 відсутністю ризику надання пріоритетності в процесі розподілу та перерозподілу економічних благ і фрінансових потоків на користь тієї чи іншої категорії стейкхолдерів.

На рівні підприємницьких структур забезпечення фрінансово-економічної безпеки зводиться до підтримання індикаторів їх фрінансового стану в межах рекомендованих значень. У великих компаніях окремі завдання менеджменту фінансово-економічної безпеки можуть виконуватися в рамках функціонування систем ризик-менеджменту або антикризового управління. Однак не потрібно забувати про те, що метою забезпечення фрінансово-економічної безпеки суб'єкта господарської діяльності $€$ саме недопущення такого його стану, що може перейти в активну стадію банкрутства. Отже, як теоретичні, так і прикладні аспекти забезпечення фрінансово-економічної безпеки на мікро- та макрорівнях не втрачають актуальності для розгляду та вивчення й потребують систематизації та уточнення 3 огляду на ті економічні реалії, що спостерігаються нині в Україні.

Аналіз останніх досліджень і публікацій. Проблематика забезпечення фрінансово-економічної безпеки на рівні підприємницьких структур знайшла відображення в роботах багатьох вітчизняних дослідників. Так, Н.В. Зачосова пропонує концептуальні засади формування комплексної системи забезпечення фрінансово-економічної безпеки підприємств та фрінансових установ України [1], а також окреслює перспективні у сучасних економічних умовах напрями забезпечення фрінансової безпеки суб'єктів господарської діяльності [2]. О.М. Герасименко опікується питаннями фрормування системи складових економічної безпеки торговців цінними паперами [3]. Колектив дослідників [4] пропонує структурно-фрункціональну модель системи економічної безпеки підприємства як елемент забезпечення фрінансово-економічної безпеки вітчизняних бізнес-структур. B.О. Занора вивчає можливості управління системою економічної безпеки підприємства на основі проектного підходу [5]. Механізм забезпечення фрінансово-економічної безпеки держави має свої характерні особливості, як зазначено в джерелі [6].

О.В. Іващенко та В.М. Гельман досліджують основи забезпечення фрінансово-економічної безпеки держави [7; 8]. В.Г. Гончар відшукує причинно-наслідкові зв'язки між станом фрінансово-економічної безпеки держави та рівнем 
фрінансово-економічної безпеки учасників економічної системи [9]ю А.Ю. Ковальчук пропонує систему сучасних принципів механізму забезпечення фрінансово-економічної безпеки країни [10]. Таким чином, у вітчизняній науковій площині загалом закладено основи розроблення концептуальних засад забезпечення фрінансово-економічної безпеки на мікро- та макрорівнях, однак для забезпечення дієвості механізму управління фрінансово-економічною безпекою вони потребують систематизації та впорядкування.

Метою статті $€$ узагальнення та уточнення основ забезпечення фрінансово-економічної безпеки на мікро- та макрорівнях з урахуванням вітчизняних реалій поточного стану розвитку економіки України.

Виклад основного матеріалу дослідження. Вивчення наукової літератури дає змогу зробити висновок про відсутність належного розуміння у науковій громаді сутності процесу забезпечення фінансово-економічної безпеки. 3 одного боку він $€$ набором заходів та інструментів, що використовуються для досягнення стану захищеності ресурсів держави або господарської структури від негативного впливу на них зовнішніх та внутрішніх небезпек і загроз. 3 іншого боку, він є системою кроків для організації протидії можливості неповній реалізації економічних та фінансових інтересів об'єкта та всіх його категорій стейкхолдерів через наявність у процесі його функціонування негативних факторів впливу на результати його фрінансово-господарської діяльності. 3 огляду на це запропоновано авторський підхід до розуміння сутності процесу забезпечення фрінансовоекономічної безпеки, а також до трактування самого поняття фрінансово-економічної безпеки. Під фрінансово-економічною безпекою пропонуємо розуміти такий стан організації використання наявних у суб'єкта ресурсів, що дає змогу забезпечити досягнення економічної мети його існування та максимально реалізувати фрінансово-економічні інтереси як самого суб'єкта, так і всіх категорій його стейкхолдерів. Забезпеченням фрінансово-економічної безпеки пропонуємо вважати комплекс заходів щодо пошуку та використання інструментарію виявлення, протидії загроз, небезпек та ризиків фрінансово-економічної діяльності суб'єкта, а також компенсації наслідків їх негативного впливу й попередження їх виникнення в перспективі. Крім цього, до забезпечення безпеки слід віднести також сукупність заходів щодо пошуку ресурсів на організацію системи фрінансово-економічної безпеки та фрінансування їі функціонування, а за необхідності - модернізації та розвитку.
Пропонована дефініція має багато спільних рис та точок дотику з визначенням категорії ризик-менеджменту, під яким розуміють процес прийняття та виконання управлінських рішень, спрямованих на зниження ймовірності виникнення несприятливого результату від ризику, а також мінімізацію можливих втрат, викликаних його реалізацією. Однак досліджуване нами поняття $€$ теоретично та практично більш широким, оскільки передбачає створення сукупності оптимальних економічних та фрінансових умов для розвитку економічної системи держави, регіону чи окремого суб'єкта господарської діяльності для його функціонування, а також управління ризиками, що виникають у такому середовищі, і це складає лише одне із завдань менеджменту фінансово-економічної безпеки.

Концептуальні засади фрінансово-економічної безпеки на національному рівні повинні бути розроблені відповідно до пріоритетних цілей та завдань досягнення високого рівня безпеки, конкретизувати шляхи та методи забезпечення захисту фрінансових та економічних ресурсів. Основи безпеки, закріплені на державному рівні, покликані координувати загальнодержавні дії у сорері забезпечення фрінансово-економічної безпеки на рівні окремих членів суспільства, учасників економічних відносин, суб'єктів господарювання, галузей, секторів національного господарства, а також на регіональному, національному та міжнародному рівнях внутрішньої та зовнішньої економічної політики.

До елементів механізму комплексного забезпечення фрінансово-економічної безпеки на мікро- та макрорівнях мають входити такі елементи, як концепція, стратегія, програма, політика, об'єкти, суб'єкти, принципи та ресурси забезпечення безпеки. Механізм забезпечення фрінансово-економічної безпеки повинен функціонувати на основі розроблення та впровадження на методологічному рівні відповідних наукових теорій, концепцій, стратегій та тактик, проведення раціональної та ефективної фрінансової політики, конкретизації об'єктів, що потребують захисту в межах вітчизняної економічної та/або фрінансової системи, визначення та започаткування необхідних інституційних структур для забезпечення безпеки, усвідомлення та слідування економічним та фрінансовим інтересам тощо.

Забезпечення фрінансово-економічної безпеки $€$ цілеспрямованою та перманентною діяльністю (господарською, організаційною, нормотворчою, аналітичною, оперативно-розшуковою тощо) всіх суб'єктів фрінансово-економічної безпеки щодо захисту власних економічних інтересів. 
Основними етапами забезпечення фінансово-економічної безпеки на мікро- та макрорівнях є ідентифікація та конкретизація економічних і фрінансових інтересів у кожній сфері національного господарства (макрорівень) та за кожним видом діяльності суб'єкта господарювання (основною, фрінансовою, інвестиційною); розроблення механізмів прогнозування, ідентифікації та оцінювання загроз фінансовоекономічній безпеці; побудова системи протидії наявним та потенційним загрозам фрінансово-економічній безпеці та компенсації їх негативних наслідків; розроблення механізмів ефективної взаємодії всіх суб'єктів забезпечення фінансово-економічної безпеки.

Доцільно приділити увагу наявним особливостям функціонування сучасних систем фінансово-економічної безпеки держави та підприємств у вітчизняних економічних реаліях. На державному рівні ними є фрінансова залежність від міжнародних організацій та фондів, відсутність структур, відповідальних за забезпечення саме фрінансово-економічної безпеки (відсутність конкретного суб'єкта управління не дає змогу ефективно працювати механізмам моніторингу, регулювання та контролювання стану безпеки), низький рівень боргової та бюджетної безпеки (високі показники внутрішньої та зовнішньої заборгованості, сталий бюджетний дефіцит, великі витрати на обслуговування державного боргу тощо), знищення системи валютної безпеки (відмова від регулювання валютного курсу, стрімка девальвація національної валюти, різкі та неконтрольовані коливання курсів валют), тривале очищення банківської системи від учасників, неспроможних виконувати свої зобов'язання (посилення фрінансового тиску на Фонд гарантування вкладів фізичних осіб, втрата довіри широких верств населення до банківських послуг, відмова від використання інших фрінансових продуктів, як наслідок, недостатньо високий рівень фінансової інклюзії), спроби запровадження спліту функцій національних регуляторів ринків фінансових послуг (перехід до нової системи регулювання фінансового ринку та його професійних учасників) тощо.

На рівні суб'єктів господарської діяльності особливості виявляються у залученні сторонніх осіб для вжиття заходів з безпеки (аутсорсинг, лізинг персоналу), наданні переваги компенсації наслідків загроз перед їх своєчасною ідентифрікацією та можливістю уникнення, забезпеченні безпеки виключно силовими засобами у більшості випадків, розподілі функцій забезпечення безпеки між різними структурними підрозділами тощо.
Аналіз особливостей процесу забезпечення фонансово-економічної безпеки в Україні дав змогу виявити низку недоліків організації управління фрінансово-економічною безпекою на прикладному рівні. Так, важливою управлінською проблемою залишається наявність суперечностей між наявними фінансово-економічними інтересами держави, суб'єктів господарської діяльності та суспільства, між інтересами України та інших держав у сфрері міжнародних економічних відносин, у межах глобальної фрінансової системи, вибудовування сприятливих умов для реалізації фрінансово-економічних інтересів всіх суб'єктів господарських взаємовідносин. До інших проблем доцільно віднести відсутність періодичного моніторингу рівня фрінансово-економічної безпеки, фррагментарність структури ії систем, відсутність якісного документаційного забезпечення процесу управління безпекою, недофінансування заходів захисту від негативного впливу небезпек і загроз, низький рівень підготовки фахівців з безпеки до вирішення різновекторних завдань та швидкого реагування на прояви ризиків тощо.

Шляхами оптимізації забезпечення фінансово-економічної безпеки в найближчій перспективі можуть стати формування комплексних систем фрінансово-економічної безпеки, об'єднання завдань забезпечення безпеки в межах одного структурного підрозділу (владної структури), збільшення витрат на фрінансування заходів, орієнтованих на безпеку, відмова від надмірно ризикових видів економічної активності.

До стратегічних орієнтирів зміцнення стану фрінансово-економічної безпеки сучасних підприємств і держави загалом належать орієнтація на досягнення стану фінансової незалежності; протидія небезпекам і загрозам на стадії їх виникнення; формування кадрового та документаційного наповнення функціонування систем фрінансово-економічної безпеки; розширення меж використання страхування як інструмента забезпечення фрінансово-економічної безпеки.

У табл. 1 узагальнено, систематизовано елементи забезпечення фрінансово-економічної безпеки на мікро- та макрорівнях.

Отже, конкретизація компонентного складу процесу забезпечення фінансово-економічної безпеки дала змогу виявити проблеми, що стають на заваді досягненню її високого рівня у сучасних українських реаліях, а також встановити перелік напрямів їх усунення в довгостроковій та поточній перспективах.

Висновки 3 проведеного дослідження. Забезпеченням фрінансово-економічної без- 
Елементи забезпечення фінансово-економічної безпеки

\begin{tabular}{|c|c|c|}
\hline Елемент & Державний рівень & Рівень підприємницьких структур \\
\hline $\begin{array}{l}\text { Система } \\
\text { фрінансово- } \\
\text { економічної } \\
\text { безпеки }\end{array}$ & \begin{tabular}{|l|} 
Підсистеми банківської, бюджетної, \\
боргової, грошово-кредитної, валютної \\
безпеки, безпеки небанківського \\
фрінансового сектору.
\end{tabular} & $\begin{array}{l}\text { Підсистеми фрінансової, інтелектуально- } \\
\text { кадрової, інфоромаційно-аналітичної, } \\
\text { матеріальної, силової (фрізичної), } \\
\text { юридичної (правової), ринкової, } \\
\text { законодавчо-політичної безпеки. }\end{array}$ \\
\hline $\begin{array}{l}\text { Суб'єкти } \\
\text { забезпечення }\end{array}$ & $\begin{array}{l}\text { Органи державної влади, національні } \\
\text { регулятори фрінансового ринку. }\end{array}$ & $\begin{array}{l}\text { Служба безпеки, відповідальні за стан } \\
\text { безпеки особи. }\end{array}$ \\
\hline $\begin{array}{l}\text { Інфрормаційні } \\
\text { засади }\end{array}$ & $\begin{array}{l}\text { Стратегія безпеки, державна програма } \\
\text { безпеки (за наявності), нормативно- } \\
\text { правові акти, накази, розпорядження } \\
\text { регуляторів фрінансового ринку. }\end{array}$ & $\begin{array}{l}\text { Концепція забезпечення безпеки } \\
\text { (за наявності), фрінансова звітність, } \\
\text { посадові інструкції, документи про } \\
\text { нерозголошення комерційної таємниці } \\
\text { (за наявності). }\end{array}$ \\
\hline $\begin{array}{l}\text { Кадровий } \\
\text { компонент }\end{array}$ & $\begin{array}{l}\text { Державні службовці, на яких } \\
\text { покладено функції забезпечення } \\
\text { безпеки. }\end{array}$ & $\begin{array}{l}\text { Професіонали з фінансово-економічної } \\
\text { безпеки, інші особи, на яких покладено } \\
\text { функції забезпечення безпеки. }\end{array}$ \\
\hline $\begin{array}{l}\text { Механізм } \\
\text { управління }\end{array}$ & $\begin{array}{l}\text { Сукупність взаємопов'язаних } \\
\text { управлінських рішень, спрямованих } \\
\text { на досягнення високого рівня } \\
\text { фінансово-економічної безпеки } \\
\text { держави, реалізацію їі економічних } \\
\text { та фрінансових інтересів, інтересів } \\
\text { громадян та суб'єктів господарської } \\
\text { діяльності в умовах наявності } \\
\text { економічних і фрінансових загроз } \\
\text { функціональному стану системи } \\
\text { фінансово-економічної безпеки. }\end{array}$ & $\begin{array}{l}\text { Сукупність взаємопов'язаних } \\
\text { управлінських рішень, спрямованих на } \\
\text { досягнення високого рівня фрінансово- } \\
\text { економічної безпеки суб'єкта } \\
\text { господарювання, реалізацію його } \\
\text { економічних та фінансових інтересів, } \\
\text { інтересів його стейкхолдерів, } \\
\text { збереження та ефективне } \\
\text { використання корпоративних } \\
\text { ресурсів в умовах наявності } \\
\text { економічних і фінансових загроз для } \\
\text { результативності цього процесу. }\end{array}$ \\
\hline $\begin{array}{l}\text { Ресурси, засоби, } \\
\text { інструменти }\end{array}$ & $\begin{array}{l}\text { Регулювання, моніторинг, контроль, } \\
\text { нагляд. }\end{array}$ & $\begin{array}{l}\text { Технології ризик-менеджменту, } \\
\text { антикризового управління. }\end{array}$ \\
\hline
\end{tabular}

пеки пропонуємо вважати комплекс заходів щодо пошуку та використання інструментарію виявлення, протидії загрозам, небезпекам і ризикам фрінансово-економічній діяльності суб'єкта, а також компенсації наслідків ïx негативного впливу та попередження їх виникнення в перспективі. До переліку проблем забезпечення фрінансово-економічної безпеки на мікро- та макрорівнях у вітчизняних реаліях доцільно віднести неврегульованість державних, підприємницьких, особистих фрінансово-економічних інтересів, відсутність періодичного моніторингу рівня фрінансовоекономічної безпеки, фрагментарність структури її систем, відсутність документаційного забезпечення процесу управління безпекою, недофрінансування заходів захисту від негативного впливу небезпек і загроз, низький рівень підготовки фрахівців з безпеки до вирі- шення різновекторних завдань та швидкого реагування на прояви ризиків.

До елементів забезпечення фрінансово-економічної безпеки належать система фрінансовоекономічної безпеки, суб'єкти забезпечення, інформаційні засади, кадровий компонент, механізм управління, ресурси, засоби, інструменти. Їх поточний стан та рівень функціональної спроможності щодо виконання покладених на них завдань визначають стан фрінансово-економічної безпеки на мікро- та макрорівнях.

Перспективи подальших досліджень вбачаємо у розробленні основ національної програми та стратегії фрінансово-економічної безпеки, а також наданні пропозицій щодо структури та змістового наповнення стратегій забезпечення фрінансово-економічної безпеки суб'єктів господарювання різних видів економічної діяльності. 


\section{Список використаних джерел:}

1. Зачосова Н.В., Шостак А.В. Концептуальні засади формування комплексної системи забезпечення фрінансово-економічної безпеки підприємств та фрінансових установ України. Економіка та держава. 2016. № 7. С. 80-83.

2. Зачосова Н.В., Бибик А.М. Напрями забезпечення фрінансової безпеки суб'єктів господарської діяльності. Науковий вісник Ужгородського начіонального університету. Серія: Міжнародні економічні відносини та світове господарство. 2017. Вип. 15 (1). С. 25-28.

3. Герасименко О.М. Формування системи складових економічної безпеки торговців цінними паперами. Інвестиції: практика та досвіd. 2011. № 1. С. 37-39.

4. Данченко О.Б., Поскрипко Ю.А., Занора В.О. Структурно-фрункціональна модель системи економічної безпеки підприємства. Вісник Черкаського університету. Серія: Економічні науки. 2016. № 3. С. 48-53.

5. Занора В.О., Сільченко Б.І. Управління системою економічної безпеки підприємства на основі проектного підходу. Економічний вісник Запорізької державної інженерної академії. 2017. Вип. 5 (1). С. 130-133.

6. Зачосова Н.В., Коваленко А.О. Методологія наукових досліджень проблем забезпечення економічної безпеки держави. Економіка та держава. 2017. № 11. С. 56-59.

7. Іващенко О.В., Гельман В.М. Фінансово-економічна безпека держави. Збірник наукових праць Таврійського державного агротехнологічного університету (економічні науки). 2013. № 2 (1). C. 121-131.

8. Іващенко О.В., Гельман В.М. Забезпечення фрінансово-економічної безпеки держави. Вісник Київського інституту бізнесу та технологій. 2013. Вип. 3. С. 13-17.

9. Гончар В.Г. Фінансово-економічна безпека підприємств України - запорука фрінансової безпеки держави. Актуальні проблеми економіки. 2015. № 8. С. 150-158.

10. Ковальчук А.Ю. Система сучасних принципів механізму забезпечення фрінансово-економічної безпеки держави. Вісник Запорізького національного університету. Юридичні науки. 2017. № 1. C. 62-69. 